\title{
PROFIL PEMECAHAN MASALAH ETNOMATEMATIKA PADA MATERI GEOMETRI BAGI SISWA BERKEMAMPUAN MATEMATIKA TINGGI
}

\author{
Mini Tika Selviani' ${ }^{1}$, Rasiman $^{2}$, Agnita Siska Pramasdyahsari ${ }^{3}$ \\ Pendidikan Matematika, Universitas PGRI Semarang ${ }^{1,2,3}$ \\ minitikaselviani@gmail.com ${ }^{1}$, mpdrasiman@yahoo.co.id ${ }^{2}$, \\ agnitasiska@upgris.ac.id ${ }^{3}$
}

\begin{abstract}
Abstrak
Penelitian ini bertujuan untuk mengetahui profil pemecahan masalah etnomatematika pada materi geometri bagi siswa berkemampuan matematika tinggi. Penelitian ini termasuk penelitian kualitatif deskriptif. Subjek yang diambil adalah satu siswa kelas VIII yang memiliki kemampuan matematika tinggi. Pengumpulan data yang dilakukan yaitu dengan tes kemampuan matematika, tes pemecahan masalah etnomatematika, dan wawancara. Teknik analisis data dilakukan melalui tiga tahapan yaitu reduksi, penyajian, penarikan kesimpulan. Keabsahan data menggunakan triangulasi metode yaitu membandingkan hasil tes pemecahan masalah etnomatematika dengan hasil wawancara. Analisis dikembangkan berdasarkan indikator kemampuan pemecahan masalah dengan memperhatikan kemampuan matematika siswa. Berdasarkan hasil analisis, etnomatematika dapat meningkatkan kemampuan matematika yang berdampak pada meningkatnya kemampuan pemecahan masalah yang dimiliki siswa. Pemecahan masalah berbasis etnomatematika pada materi geometri lebih mempermudah siswa dalam mengekspresikan pengetahuan dan keterampilan matematika siswa. Hal ini dibuktikan bahwa subjek dengan kemampuan matematika tinggi juga memiliki kemampuan pemecahan masalah tinggi.
\end{abstract}

Kata kunci: kemampuan pemecahan masalah, etnomatematika.

\begin{abstract}
This study aims to determine the profile of ethnomathematics problem solving in geometry material in terms of students' mathematical abilities. This type of research is a descriptive qualitative research. The subject taken were one class VIII student who had high mathematical abilities. Data collection was carried out by means of a math ability test, ethnomathematics problem solving test, and interviews. The data analysis technique was carried out in three stages, namely reduction, presentation, and drawing conslusions. The validity of the data used triangulation method, which is to compare the results of ethnomathematics problem solving tests with the results of interviews. The analysis was developed based on indicators of problem-solving abilities with attention to students' mathematical abilities. Based on the results of the analysis, ethnomathematics can inprove
\end{abstract}


Prismatika: Jurnal Pendidikan dan Riset Matematika Vol. 3 No. 2 (2021)

p-ISSN: 2654-6140, e-ISSN: 2656-4181

http://ejurnal.budiutomomalang.ac.id/index.php/prismatika

mathematical skills which have an impact on increasing the problemsolving abilities of students. Ethnomathematics based problem solving in geometry material makes it easier for students to express student's mathematical knowledge and skills. It is proven that subjects with high mathematical abilities also have high problem solving abilities.

Keywords: problem solving ability, ethnomathematics.

\section{PENDAHULUAN}

Proses berpikir matematika terdiri dari lima kompetensi standar yaitu: (1) kemampuan pemecahan masalah, (2) penalaran, (3) koneksi, (4) komunikasi, dan (5) kemampuan representasi (NCTM, 2000) . Pentingnya pemecahan masalah dalam pembelajaran disampaikan oleh National Council of Teacher of Mathematics (NCTM). (Polya, 1973) mendefinisikan bahwa pemecahan masalah merupakan usaha mencari solusi dari suatu kesulitan. Sedangkan menurut Sajadi, Amiripour, \& Malkhalifeh (2013) dalam hasil penelitian mengungkapkan bahwa dengan adanya proses pemecahan masalah merupakan salah satu elemen penting dalam menggabungkan masalah kehidupan nyata. Hasil survei internasional hasil tes TIMSS untuk kelas 8 pada tahun 2019 yang diselenggarakan oleh IEA yaitu Indonesia berada di peringkat 44 dan 49 negara dengan hasil rata - rata skor Indonesia 397 dan rata - rata skor Internasional 500. Salah satu penyebab rendahnya peringkat Indonesia adalah kemampuan siswa dalam memecahkan masalah.

Rendahnya kemampuan ini akan berakibat pada rendahnya kualitas sumber daya manusia, yang ditunjukan dalam rendahnya kemampuan pemecahan masalah. Menurut Ilyyana \& Rochmad (2018) rendahnya kemampuan untuk memecahkan masalah matematika adalah karena kurangnya pembiasaan dalam penyelesaian masalah yang terkait dengan situasi kehidupan sehari - hari dan model pembelajaran yang digunakan tidak sesuai dengan nilai - nilai budaya lokal. Maka perlu adanya pembelajaran matematika yang diterapkan dalam pembelajaran berbasis budaya atau lebih sering disebut "etnomatematika". Seperti yang disampaikan Rosa \& Orey (2011) penerapan perspektif etnomathematis dalam kurikulum matematika sekolah membantu mengembangkan pembelajaran intelektual, sosial, emosional, dan politik siswa dengan menggunakan referensi budaya mereka sendiri yang unik untuk menanamkan pengetahuan, keterampilan, dan sikap mereka. Pada dasarnya konsep - konsep ini terkait dengan budaya siswa dan pengalaman sehari hari yang dapat meningkatkan kemampuan mereka untuk memperdalam pemecahan masalah. 
Hasil analisis soal TIMSS 2011 yaitu karakteristik soal dengan indeks kesukaran tinggi bagi siswa SMP Indonesia dengan domain kognitif penerapan dan penalaran masih menjadi sebuah soal dengan indeks kesukaran yang tinggi. Seperti pada soal geometri dengan domain kognitif penerapan dan penalaran memiliki presentase jawaban benar $25 \%$ dan $0 \%$ (Shodiq \& Tirta, 2012). Sedangkan menurut Sumiyati, Netriwati, \& Rakhmawati (2018) berdasarkan kurikulum 2006, porsi yang sangat besar didapatkan pada pelajaran geometri pada jenjang SMP jika dibandingkan dengan beberapa materi yang lain. Hal ini mengindikasikan bahwa geometri merupakan salah satu komponen paling penting pada kurikulum matematika (Yuliyanto \& Jailani, 2014).

Namun sangat memprihatinkan, faktanya kemampuan matematika siswa di Indonesia masih tergolong rendah. Hasil studi PISA tahun 2012 menunjukkan bahwa kemampuan matematika siswa yang di Indonesia berada di tingkat 63 dari 64 negara dengan skor rata - rata 375 OECD pada tahun 2014. Kemudian pada tahun 2015, Indonesia memperoleh skor rata rata matematika sebesar 386 pada OECD tahun 2018. Akibatnya, kehawatiran ketidakmampuan siswa dalam menerapkan pembelajaran matematika untuk menyelesaikan masalah dalam kehidupan sehari - hari Hiebert, J. \& Carpenter, T.P., 1992 dalam (Masamah, 2018). Widarti (2013) juga mengungkapkan bahwa kemampuan matematika setiap siswa berbeda beda, ada siswa yang memiliki kemampuan tinggi, sedang, rendah. Depdiknas (2009) membuat kriteria tingkat kemampuan siswa dan skala penilaiannya menjadi 3 kategori yaitu kemampuan tinggi jika $80 \leq$ nilai yang diperoleh $\leq$ 100, kemampuan sedang jika $65 \leq$ nilai yang diperoleh $<80$, dan kemampuan rendah jika $0 \leq$ yang diperoleh $<65$.

Fakta yang terjadi di lapangan, hasil penelitian yang sudah dilakukan oleh (Anhar, Triyanto, \& Chrisnawati, 2019) terhadap siswa SMP N 2 Plupuh, Sragen mengungkapkan bahwa kemampuan pemecahan masalah matematika siswa, khususnya kelas VIII, sebagian besar masih rendah. Hal tersebut terlihat pada hasil pengerjaan soal Penilaian Akhir Tahun (PAT) tahun 2017/2018 siswa. Hasil penelitian lain yang sudah dilakukan oleh (Novferma, 2016) di SMP Kabupaten Sleman DIY tahun 2012/2013 menjelaskan bahwa penguasaan materi serta dalam pemecahan masalah matematika belum maksimal, hal ini dapat dilihat dari hasil daya serap Ujian Nasional (UN). (Mawaddah \& Maryanti, 2016) juga mengemukakan bahwa masih banyak siswa yang belum paham tentang materi yang diajarkan, matematika cenderung dianggap pelajaran yang sulit dan tidak disukai, seringkali pembelajaran matematika yang dilakukan di kelas lebih banyak didominasi oleh guru bukan berpusat pada siswa. Sehingga respon siswa selama pembelajaran di kelas kurang baik, siswa cenderung pasif dan hanya 
mendengarkan apa yang disampaikan oleh guru, banyak siswa yang terlihat bosan, tidak semangat dalam belajar, bahkan ada yang malas membaca buku.

Berdasarkan praktik mengajar langsung yang telah dilakukan oleh peneliti saat melaksanakan magang di SMP Purnama 3 Semarang selama 45 hari, diperoleh informasi bahwa siswa kelas VIII SMP Purnama 3 Semarang masih mengalami kesulitan dalam memecahkan masalah. Diduga siswa belum memiliki kemampuan pemecahan masalah, hal ini dapat dilihat dari hasil soal - soal yang dikerjakan oleh siswa. Kebanyakan siswa tidak dapat menerapkan pemahaman masalah matematika pada kehidupan sehari - hari dan masih dijumpai siswa yang tidak dapat memahami soal cerita sehingga siswa kebingungan dalam mengerjakan soal. Padahal menurut Vygotsky (1978) dan (Dewey, 1916) kemampuan individu untuk berpikir dan bertindak bergantung pada kemampuan dalam berinteraksi atau berkomunikasi dengan kondisi sosial kulturalnya.

Berdasarkan uraian diatas, dilakukan analisis kemampuan pemecahan masalah etnomatematika. Salah satu sub pokok bahasan yang sesuai untuk digunakan sebagai bahan tes pemecahan masalah adalah materi geometri. Soal tes yang diberikan berkaitan dengan budaya dan kehidupan sehari hari sehingga menuntut kemampuan siswa dalam memecahkan masalah. Oleh karena itu, peneliti melakukan penelitian untuk mengetahui kemampuan pemecahan masalah etnomatematika siswa dengan judul "Profil Pemecahan Masalah Etnomatematika pada Materi Geometri Bagi Siswa Berkemampuan Matematika Tinggi".

\section{METODE PENELITIAN}

Penelitian ini merupakan jenis penelitian kualitatif deskriptif. Penelitian ini dilaksanakan di SMP Purnama 3 Semarang tepatnya dikelas VIIIB dimulai pada tanggal 14 Januari 2021 hingga 17 Februari 2021, dimana subjek penelitian sebanyak 28 siswa yang nantinya dipilih satu siswa dengan kemampuan matematika tinggi dipilih berdasarkan hasil tes kemampuan matematika siswa yang telah diisi. Indikator pemecahan masalah yang digunakan dalam penelitian ini menurut (Polya, 1985) antara lain: (1) memahami masalah (2) membuat rencana pemecahan masalah (3) menjalankan rencana pemecahan masalah, dan (4) memeriksa kembali hasilnya.

Langkah - langkah dalam penelitian ini adalah: tahap persiapan yaitu menyusun instrument penelitian seperti kisi - kisi tes kemampuan matematika, tes pemecahan masalah etnomatematika, membuat soal dengan indikator pemecahan masalah dan juga pedoman wawancara, kemudian melakukan validasi kepada para ahli. Tahap pelaksanaan yaitu memberikan tes kemampuan matematika siswa secara online berupa google form kepada 
Prismatika: Jurnal Pendidikan dan Riset Matematika Vol. 3 No. 2 (2021)

satu kelas, mengelompokan siswa berdasarkan hasil tes kemampuan matematika dengan kategori kemampuan matematika tinggi, kemampuan matematika sedang, kemampuan matematika rendah, kemudian dipilih satu subjek yaitu siswa dengan kemampuan matematika tinggi yang memiliki skor tertinggi dari kategori siswa tinggi untuk melakukan tes pemecahan masalah etnomatematika dan wawancara secara offline, setelah ini dilakukan analisis triangulasi berdasarkan hasil tes pemecahan masalah etnomatematika dan wawancara ntuk menarik kesimpulan dari penelitian yang dilakukan dengan menjawab rumusan masalah. Soal terdiri dari dua nomor dengan setiap nomor memuat empat indikator pemecahan masalah seperti pada gambar 1 .

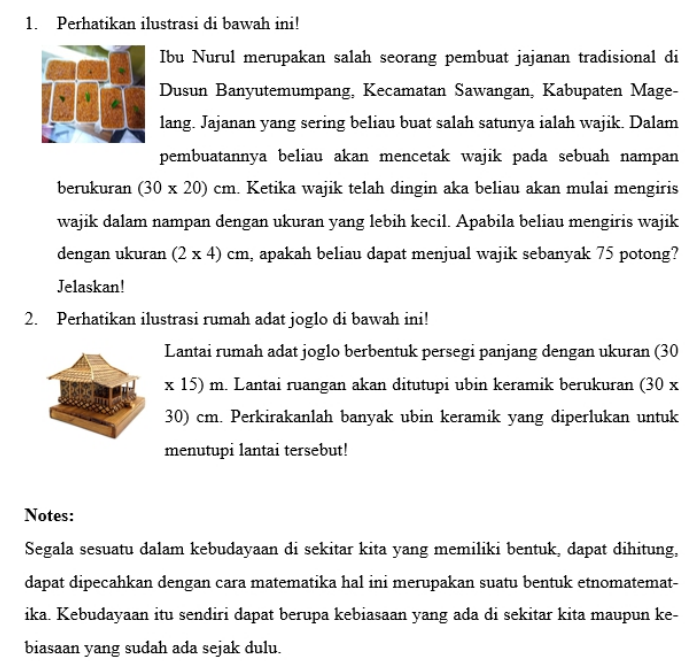

\section{Gambar 1. Soal Tes Pemecahan Masalah Etnomatematika}

Adapun kriteria untuk pemberian skor yang digunakan dalam penelitian ini menurut (Wulan, 2012) adalah sebagai berikut;

Tabel 1. Pedoman Pemberian Skor Tes Soal

\begin{tabular}{ccl}
\hline $\begin{array}{c}\text { Aspek yang } \\
\text { dinilai }\end{array}$ & Skor & \multicolumn{1}{c}{ Keterangan } \\
\hline \multirow{2}{*}{$\begin{array}{c}\text { Memahami } \\
\text { masalah }\end{array}$} & 0 & $\begin{array}{l}\text { Salah menginterpretasi soal atau tidak ada } \\
\text { jawaban sama sekali. }\end{array}$ \\
\cline { 2 - 3 } & 0,5 & $\begin{array}{l}\text { Salah menginterpretasi sebagaian soal atau } \\
\text { mengabaikan kondisi soal. }\end{array}$ \\
\cline { 2 - 3 } $\begin{array}{c}\text { Membuat } \\
\text { rencana } \\
\text { pemecahan } \\
\text { masalah }\end{array}$ & 0,5 & $\begin{array}{l}\text { Menggunakan strategi yang tidak relevan } \\
\text { atau tidak ada strategi sama sekali. }\end{array}$ \\
\cline { 2 - 3 } & 1 & $\begin{array}{l}\text { Menggunakan sebagian strategi yang benar } \\
\text { tetapi mengarah pada jawaban yang salah } \\
\text { atautidak mencoba strategi yang lain. }\end{array}$ \\
\hline $\begin{array}{c}\text { Menjalankan } \\
\text { rencana }\end{array}$ & 0 & $\begin{array}{l}\text { Menggunakan beberapa prosedur yang } \\
\text { mengarah ke solusi yang benar. }\end{array}$ \\
\cline { 2 - 3 } Tidak ada solusi sama sekali. \\
\hline
\end{tabular}


Prismatika: Jurnal Pendidikan dan Riset Matematika Vol. 3 No. 2 (2021)

\begin{tabular}{cclll}
\hline pemecahan & \multicolumn{4}{l}{ hanya perhitungan saja. } \\
\cline { 2 - 5 } masalah & 1 & Hasil dan prosedur benar. & \\
\hline Memeriksa & 0 & $\begin{array}{l}\text { Tidak ada kesimpulan atau tidak ada } \\
\text { keterangan apapun. }\end{array}$ \\
\cline { 2 - 5 } $\begin{array}{c}\text { kembali } \\
\text { hasulnya }\end{array}$ & 0,5 & Ada kesimpulan tetapi kurang tepat. \\
\cline { 2 - 5 } & 1 & $\begin{array}{l}\text { Kesimpulan dilaksanakan untuk melihat } \\
\text { keterangan hasil dan proses. }\end{array}$ \\
\hline
\end{tabular}

Klasifikasi pemecahan masalah etnomatematika dihitung menggunakan rumus menurut Djaali dan Mulyono (Armadan, 2017) :

$$
N_{i}=\frac{X_{i}}{S_{i}} \times 100
$$

Keterangan:

$\mathrm{N}_{\mathrm{i}} \quad=$ Nilai siswa

$\mathrm{X}_{\mathrm{i}} \quad=$ Jumlah skor yang diperoleh siswa

$\mathrm{S}_{\mathrm{i}} \quad=$ Jumlah skor maksimum

Depdiknas (2009) membuat kriteria tingkat kemampuan siswa dan skala penilaiannya menjadi 3 kategori yaitu;

Tabel 2. Kriteria Tingkatan

\begin{tabular}{cc}
\hline Skor & Kategori \\
\hline $100-80$ & Tinggi \\
\hline $79-65$ & Sedang \\
\hline $64-0$ & Rendah \\
\hline
\end{tabular}

\section{HASIL DAN PEMBAHASAN}

Berdasarkan hasil analisis tes kemampuan matematika mengelompokkan 28 siswa kelas VIIIB SMP Purnama 3 Semarang menjadi tiga kategori yaitu 12 siswa berkemampuan matematika tinggi, 11 siswa berkemampuan matematika sedang, 5 siswa berkemampuan matematika rendah, disajikan pada tabel 3 sebagai berikut;

Tabel 3. Kategori Kemampuan Matematika Siswa

\begin{tabular}{lcc}
\hline $\begin{array}{c}\text { Kategori Kemampuan } \\
\text { Matematika }\end{array}$ & $\begin{array}{c}\text { Banyak } \\
\text { Siswa }\end{array}$ & Persentase \\
\hline Kemampuan matematika tinggi & 12 & 42,857 \\
\hline Kemampuan matematika sedang & 11 & 39,285 \\
\hline Kemampuan matematika rendah & 5 & 17,857 \\
\hline Jumlah & 28 & 100 \\
\hline
\end{tabular}


Prismatika: Jurnal Pendidikan dan Riset Matematika Vol. 3 No. 2 (2021)

Berdasarkan hasil analisis tes kemampuan matematika pada tabel 3, pemilihan subjek penelitian dipilih satu siswa dengan skor tertinggi dari kategori tinggi untuk dianalisis kemampuan pemecahan masalah etnomatematika secara lebih lanjut. Tes soal pemecahan masalah etnomatematika diberikan kepada satu siswa berkemampuan mateatika tinggi yang sudah terpilih dan mewakili kategori kemampuan matematika tinggi. Adapun kisi - kisi tes soal pemecahan masalah etnomatematika dapat dilihat pada tabel 4 .

Tabel 4. Kisi - Kisi Tes Pemecahan Masalah Etnomatematika

\begin{tabular}{|c|c|c|}
\hline Indikator Polya & Kisi - kisi & Soal \\
\hline Memahami masalah. & \multirow{4}{*}{$\begin{array}{l}\text { Diberikan ukuran dari } \\
\text { sebuah bangun dan } \\
\text { jajanan tradisional, } \\
\text { siswa diminta } \\
\text { menentukan ukuran } \\
\text { untuk memenuhi } \\
\text { persyaratan tertentu. }\end{array}$} & \multirow{4}{*}{1 dan 2} \\
\hline $\begin{array}{l}\text { 2. Menyusun strategi atau } \\
\text { rencana penyelesaian. }\end{array}$ & & \\
\hline 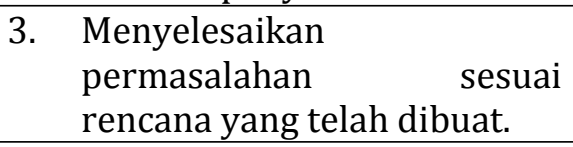 & & \\
\hline 4. Memeriksa kembali jawaban. & & \\
\hline
\end{tabular}

Berdasarkan hasil tes tulis pemecahan masalah etnomatematika dan hasil wawancara siswa diperoleh uraian sesuai jawaban siswa berkemampuan matematika tinggi sebagai berikut.

Tabel 5. Hasil Analisis Berdasarkan Jawaban Tertulis

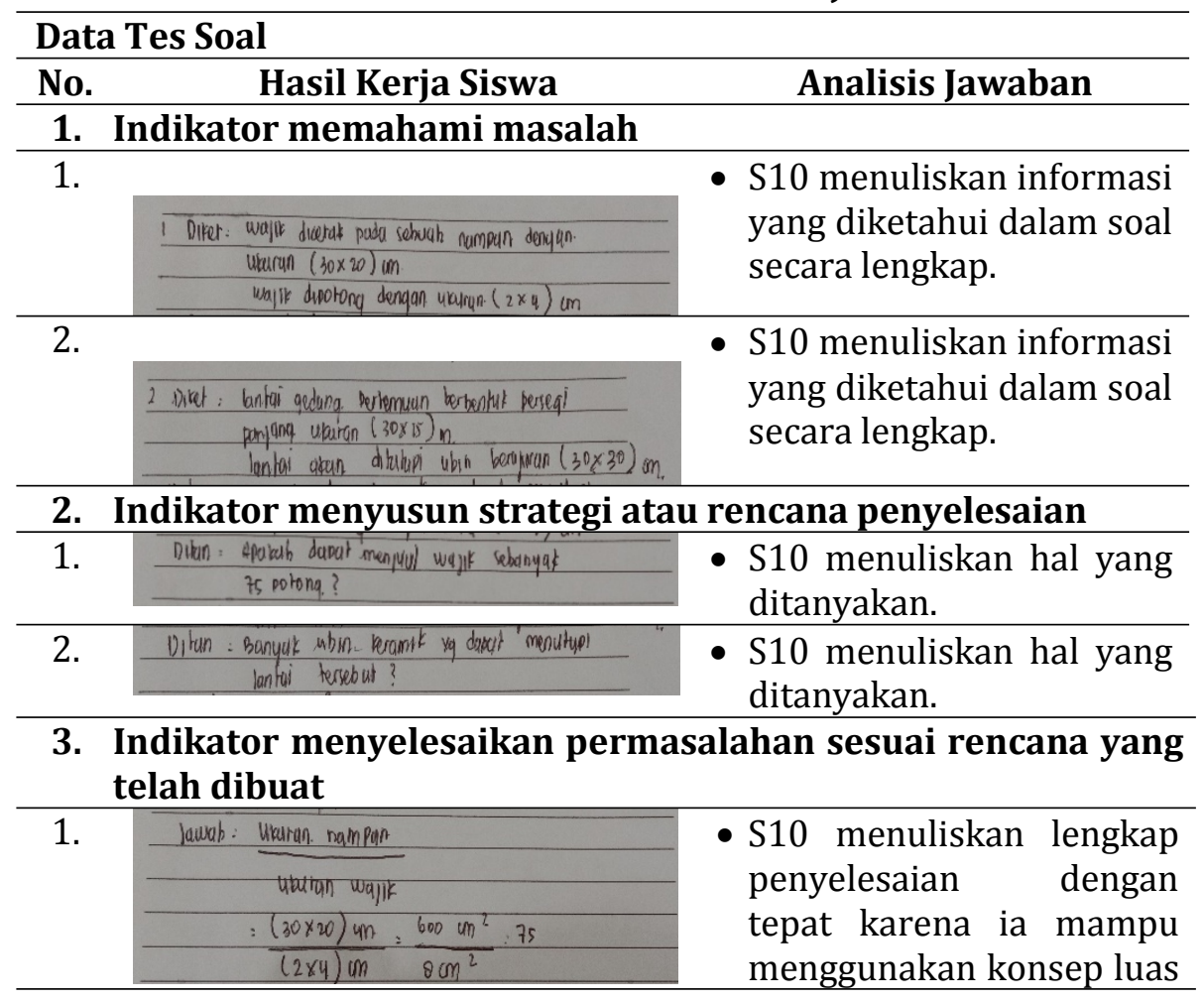




\begin{tabular}{|c|c|c|}
\hline & & $\begin{array}{l}\text { dimana ia membagi luas } \\
\text { wajik dalam nampan } \\
\text { dengan luas wajik yang } \\
\text { diinginkan. Oleh sebab itu } \\
\text { S10 mendapatkan hasil } 75 \\
\text { wajik. }\end{array}$ \\
\hline & 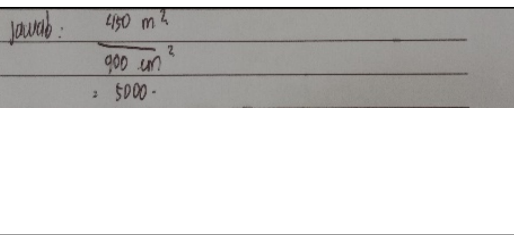 & $\begin{array}{l}\text { - S10 langsung menuliskan } \\
\text { jawaban tanpa langkah - } \\
\text { langkah penyelesaian } \\
\text { secara urut dan } \\
\text { mendapatkan hasil 5.000 }\end{array}$ \\
\hline \multicolumn{3}{|c|}{ 4. Indikator memeriksa kembali jawaban } \\
\hline 1. & 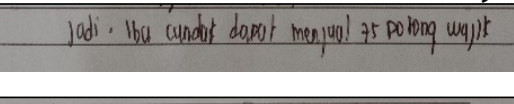 & $\begin{array}{ll}\text { - S10 menuliskan } \\
\text { kesimpulan dengan benar. }\end{array}$ \\
\hline 2. & 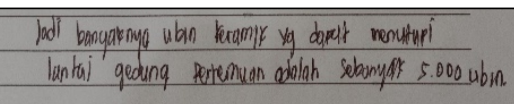 & $\begin{array}{l}\text { - S10 menuliskan } \\
\text { kesimpulan dengan benar. }\end{array}$ \\
\hline
\end{tabular}

Tabel 6. Hasil Analisis Berdasarkan Data Wawancara

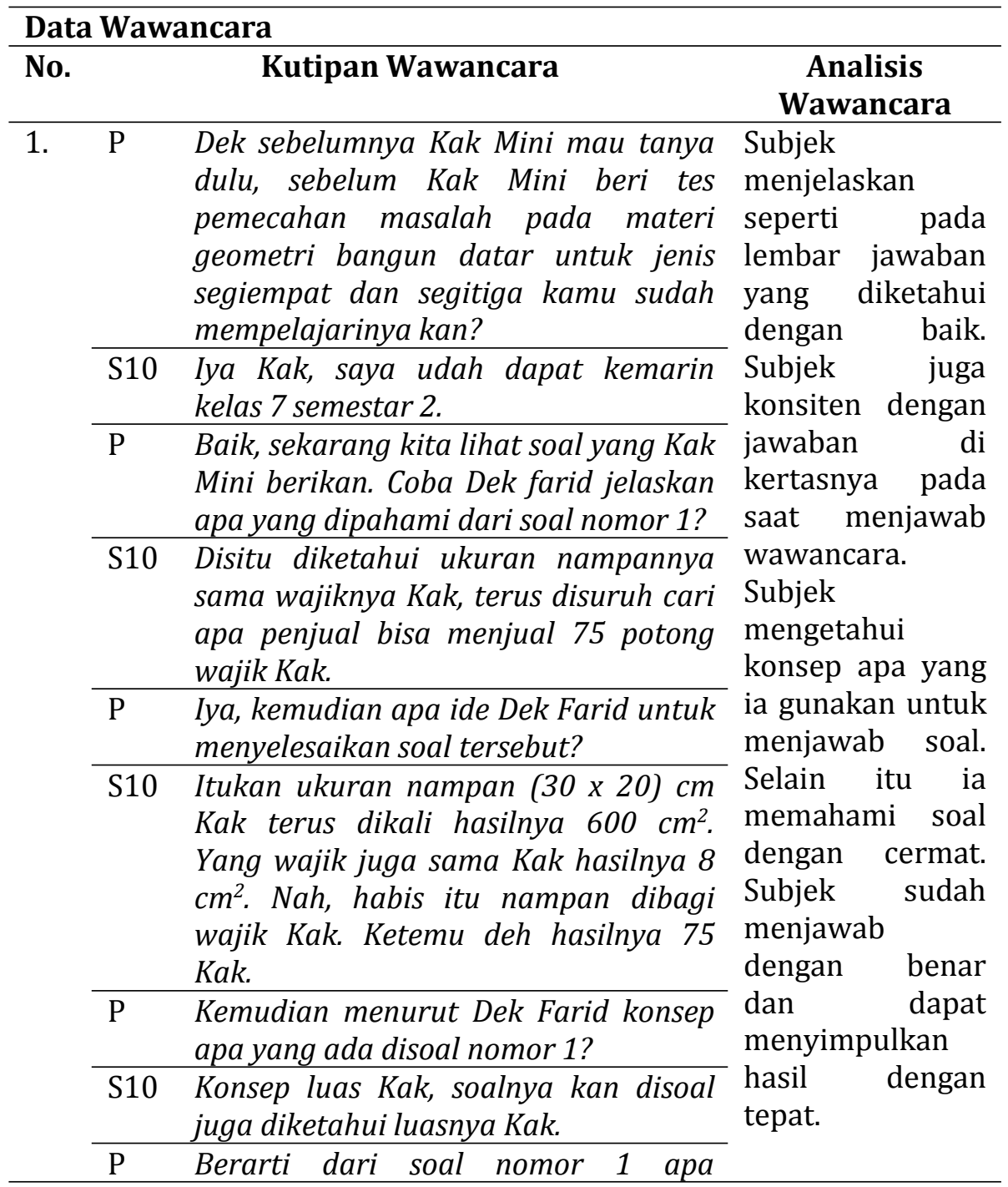


Prismatika: Jurnal Pendidikan dan Riset Matematika Vol. 3 No. 2 (2021)

\begin{tabular}{|c|c|c|c|}
\hline & & kesimpulannya Dek? & \\
\hline & S10 & $\begin{array}{l}\text { Berarti sebanyak } 75 \text { potong yang bisa } \\
\text { dijual Kak. }\end{array}$ & \\
\hline & $P$ & $\begin{array}{l}\text { Kamu sudah yakin dengan jawaban } \\
\text { kamu Dek? }\end{array}$ & \\
\hline & S10 & Yakin Kak! 100\% yakin. & \\
\hline 2. & $\mathrm{P}$ & $\begin{array}{l}\text { Ok, kita lanjut ke nomor } 2 \text { ya Dek. Dari } \\
\text { soal nomor } 2 \text { apa yang dipahami dek } \\
\text { Farid? }\end{array}$ & $\begin{array}{l}\text { Subjek } \\
\text { menjelaskan } \\
\text { seperti pada }\end{array}$ \\
\hline & S10 & $\begin{array}{l}\text { Kalo nomor } 2 \text { itu aku disuruh nentuin } \\
\text { banyak keramik yang dapat menutupi } \\
\text { lantai Kak. }\end{array}$ & $\begin{array}{l}\text { lembar jawaban } \\
\text { yang diketahui } \\
\text { dengan baik. }\end{array}$ \\
\hline & $\mathrm{P}$ & $\begin{array}{l}\text { Coba Dek Farid sebutkan apa saja } \\
\text { yang diketahui dalam soal! }\end{array}$ & \\
\hline & S10 & $\begin{array}{l}\text { Itu Kak yang diketahui lantai rumah } \\
\text { adat joglo berbentuk persegi panjang } \\
\text { dengan ukuran }(30 \times 15) \mathrm{m} \text {. emm.. } \\
\text { terus lantai ruangan yang akan } \\
\text { ditutupi keramik ukuran }(30 \times 30) \mathrm{cm} \\
\text { Kak. }\end{array}$ & $\begin{array}{l}\text { Masih ada } \\
\text { beberapa } \\
\text { langkah yang } \\
\text { dilewatkan } \\
\text { dalam } \\
\text { menjelaskan }\end{array}$ \\
\hline & $P$ & $\begin{array}{l}\text { Coba Dek Farid ceritakan apa ide Dek } \\
\text { Farid untuk menyelesaikan soal } \\
\text { tersebut! }\end{array}$ & $\begin{array}{l}\text { langkah yang } \\
\text { digunakan, } \\
\text { namun sudah }\end{array}$ \\
\hline & S10 & $\begin{array}{l}\text { Itu langsung aja Kak, } 450 \mathrm{~m}^{2} \text { dibagi } \\
900 \mathrm{~cm}^{2} . \text { Yaudah deh ketemu } 5.000 \\
\text { Kak. }\end{array}$ & $\begin{array}{ll}\text { menjawab } & \\
\text { dengan } & \text { benar } \\
\text { dan } & \text { dapat }\end{array}$ \\
\hline & $\mathrm{P}$ & Jadi nomor 2 apa kesimpulannya Dek? & menyimpulkan \\
\hline & S10 & $\begin{array}{l}\text { Kesimpulannya ya banyak ubin } \\
\text { keramik yang dapat menutupi lantai } \\
\text { sebanyak 5.000 ubin Kak. }\end{array}$ & \\
\hline & $\mathrm{P}$ & $\begin{array}{l}\text { Kamu yakin dengan jawaban kamu } \\
\text { Dek? }\end{array}$ & \\
\hline & $\mathrm{S} 10$ & Yakin dons & \\
\hline
\end{tabular}

Berdasarkan hasil tes tulis dan wawancara, selanjutnya dilakukan triangulasi seperti tabel berikut. 
Prismatika: Jurnal Pendidikan dan Riset Matematika Vol. 3 No. 2 (2021) p-ISSN: 2654-6140, e-ISSN: 2656-4181

http://ejurnal.budiutomomalang.ac.id/index.php/prismatika

Tabel 7. Triangulasi Berdasarkan Hasil Tes Tulis dan Wawancara

\begin{tabular}{|c|c|c|}
\hline Indikator & Hasil Tes Tertulis & Hasil Wawancara \\
\hline $\begin{array}{l}\text { Memahami } \\
\text { masalah }\end{array}$ & $\begin{array}{l}\text { - Menyajikan kembali } \\
\text { data atau informasi } \\
\text { yang ada pada soal. } \\
\text { - Menuliskan informasi } \\
\text { dengan benar. } \\
\end{array}$ & $\begin{array}{l}\text { - Menjelaskan informasi } \\
\text { yang ada pada soal. } \\
\text { - Menyebutkan } \\
\text { informasi dengan } \\
\text { benar. }\end{array}$ \\
\hline $\begin{array}{r}\text { Men } \\
\text { ren } \\
\text { peme } \\
\text { mas }\end{array}$ & $\begin{array}{l}\text { - Menentukan } \\
\text { atau rencana dengan } \\
\text { tepat. }\end{array}$ & $\begin{array}{l}\text { ebutkan solusi } \\
\text { ang ia gunakan. }\end{array}$ \\
\hline $\begin{array}{r}\text { Menj } \\
\text { rer } \\
\text { pem } \\
\text { ma }\end{array}$ & 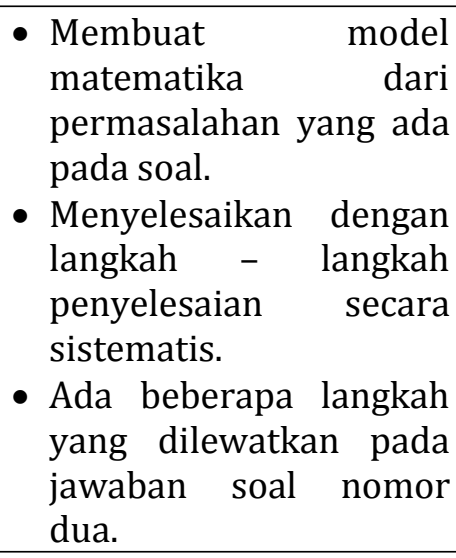 & $\begin{array}{l}\text { - Mengungkapkan dalam } \\
\text { bentuk kata - kata } \\
\text { model matematika dari } \\
\text { permasalahan. } \\
\text { - Menyebutkan langkah } \\
\text { - langkah penyelesaian } \\
\text { secara sistematis. } \\
\text { - Ada beberapa langkah } \\
\text { yang dilewatkan pada } \\
\text { jawaban soal nomor } \\
\text { dua. }\end{array}$ \\
\hline $\begin{array}{r}\text { Meme } \\
\text { kem } \\
\text { hasil }\end{array}$ & $\begin{array}{l}\text { - Menyimpulkan hasil } \\
\text { dengan benar. } \\
\text { - Menjawab soal dengan } \\
\text { benar. }\end{array}$ & $\begin{array}{l}\text { - Menyimpulkan hasil } \\
\text { dengan benar. } \\
\text { - Menjawab soal dengan } \\
\text { benar. }\end{array}$ \\
\hline
\end{tabular}

Berdasarkan hasil analisis keempat indikator pemecahan masalah terhadap subjek berkemampuan matematika tinggi, pada tes soal pemecahan masalah etnomatematika dianalisis berdasarkan rumus menurut Djaali dan Mulyono (Armadan, 2017)

$$
N_{i}=\frac{7,5}{8} \times 100=93,75
$$

Nilai pemecahan masalah yang didapatkan oleh subjek berkemampuan tinggi yaitu 93,75. Menurut Depdiknas (2009) termasuk dalam kategori tinggi.

Berdasarkan triangulasi metode dengan membandingkan hasil tertulis tes pemecahan masalah etnomatematika dan hasil wawancara, menyatakan bahwa data yang diperoleh melalui tes pemecahan masalah etnomatematika dan wawancara subjek konsisten.

Berdasarkan hasil triangulasi tersebut maka dapat dikatakan hal berikut. Subjek dapat menjawab kedua soal dengan baik dan tepat. Hal ini menunjukan bahwa subjek mampu memahami masalah dengan tepat, membuat rencana pemecahan permasalahan, menjalankan rencana 
pemecahan masalah, dan memeriksa kembali. Hal ini dibuktikan bahwa subjek dapat menyajikan kembali data atau informasi yang ada pada soal, dapat menentukan solusi atau rencana dengan tepat, dapat membuat model matematika dari permasalahan yang ada pada soal, dapat menyelesaikan dengan langkah - langkah penyelesaian secara sistematis sehingga dapat menjawab dan menyimpulkan hasil dengan benar. Sejalan dengan pendapat Listanti \& Mampouw (2020), bahwa subjek dengan kemampuan tinggi dapat memahami masalah dan menyelesaikan pemecahan soal dengan benar. Astutiningtyas (2017), berdasarkan analisis data diperoleh dengan pendekatan berbasis budaya atau etnomatematika menghasilkan kemampuan pemecahan masalah yang lebih baik. Sirate (2012) juga mengatakan bahwa penerapan etnomatematika sebagai sarana untuk memotivasi, menstimulasi peserta didik, dapat mengatasi kejenuhan dan kesulitan dalam belajar matematika.

\section{KESIMPULAN DAN SARAN}

Berdasarkan uraian deskripsi data serta analisis data dapat disimpulkan bahwa dengan menggunakan pendekatan berbasis budaya (etnomatematika) pada materi geometri siswa dengan kemampuan matematika tinggi dapat menggunakan empat indikator pemecahan masalah dengan maksimal, mampu mengungkapkan ide - ide pemecahan masalah untuk menyelesaikan suatu persoalan berbasis etnomatematika. Dalam proses mengerjakan tes pemecahan masalah etnomatematika, siswa tidak mudah menyerah, semangat, dan ulet. Hal ini membuktikan bahwa siswa dengan kemampuan matematika tinggi juga memiliki kemampuan pemecahan masalah tinggi. Berdasarkan pernyataan tersebut dapat dikatakan bahwa etnomatematika dapat meningkatkan kemampuan matematika yang berdampak pada meningkatnya kemampuan pemecahan masalah yang dimiliki siswa.

Penelitian ini terdapat keterbatasan pada pembahasan penyelesaian soal berbasis etnomatematika budaya yang digunakan masi berpusat di Jawa Tengah khususnya Magelang belum mencakup seluruh budaya di Indonesia, selain itu penelitian ini hanya dilakukan pada tingkat SMP untuk materi geometri bangun datar (jenis segiempat dan segitiga).

Peneliti memberikan saran bagi peneliti yang ingin melakukan penelitian lebih lanjut dapat memperluas budaya yang digunakan. Bagi guru sebaiknya dalam pembalajaran lebih menerapkan pembelajaran matematika yang berkaitan dengan kehidupan sehari - hari siswa atau budaya yang unik. Bagi siswa sebaiknya sering berlatih untuk menemukan jawaban - jawaban pada soal dengan beragam pemecahan masalah. 


\section{DAFTAR PUSTAKA}

Anhar, L. N., Triyanto, \& Chrisnawati, H. E. (2019). Analisis Kemampuan Pemecahan Masalah Matematika Pada Materi Geometri Berdasarkan Langkah Polya Ditinjau Dari Kemampuan Representasi Matematis Siswa Kelas VIII SMPN 2 Plupuh Tahun 2018/2019. JPMM, 3 (1), 515524.

Armadan, D. (2017). Kemampuan Representasi Matematis Siswa Pada Pembelajaran Berbasis Teori Van Hiele di Materi Segiempat Kelas VII SMP Negeri 1 Indralayu Utara. Jurnal Eternal, 3(1).

Astutiningtyas, E. L., Wulandari, A. A., \& Farahsanti, I. (2017). Etnomatematika Dan Pemecahan Masalah Kombinatorik. Jurnal Math Educator Nusantara, 3 (2), 59-134.

Depdiknas. (2009). Permendiknas RI Nomor. 22 tahun 2006 tentang Standar Isi.

Retrieved

from https://akhmadsudrajat.files.wordpress.com/2009/04/permendikna s-no-22-tahun-2006.pdf:

https://www.google.com/search?q=permendiknas-no-22-tahun2006\&rlz=1C1ASVC_idID917ID917\&oq=permendiknas-no-22-tahun2006\&aqs $=$ chrome...69i57j0i3017.898j0j15\&sourceid=chrome\&ie=UT F-8

Dewey, J. (1916). Democracy and Education. United States of America: MacMillan.

Ilyyana, K., \& Rochmad. (2018). Analysis of Problem Solving Ability Quadrilateral Topic on Model Eliciting Activities Learning Containing Ethnomathematics. UJMER, 7(2), 130-137.

Listanti, D. R., \& Mampouw, H. L. (2020). Profil Pemecahan Masalah Geometri Oleh Siswa SMP Ditinjau dari Perbedaan Kemampuan Matematika. Jurnal Pendidikan Matematika, 4(1), 365-379.

Masamah, U. (2018). Pengembangan Pembelajaran Matematika dengan Pendekatan Etnomatematika Berbasis Budaya Lokal Kudus. Jurnal Pendidikan Matematika, 1(2), 124-125.

Mawaddah, S., \& Maryanti, R. (2016). Kemampuan Pemahaman Konsep Matematis Siswa SMP dalam Pembelajaran Menggunakan Model Penemuan Terbimbing (Discovery Learning). EDU-MAT Jurnal Pendidikan Matematika, 4 (1), 77.

NCTM. (2000). Principles and Standards. Reston.

Novferma, N. (2016). Analisis Kesulitan dan Self Efficiancy Siswa SMP dalam Pemecahan Masalah Matematika Berbentuk Soal Cerita. Jurnal Riset Pendidikan Matematika, 3 (1), 76-87.

OECD. (2014). PISA 2012 Result in Focus: What 15-Year-Olds Know and What They Can Do With What They Know.

OECD. (2018). PISA 2015 Result in focus. OECD.

Polya, G. (1973). How to Solve It. New Jersey: Princeton University Press.

Polya, G. (1985). How to Solve it: A new aspect of mathematics method. Princetonn: University Press.

Rosa, M., \& Orey, D. C. (2011). Ethnomathematics: the cultural aspects of mathematics. Revista Latinoamericana de Etnomatematica, 4(2), 32-54. 
Sajadi, M., Amiripour, M. R., \& Malkhalifeh, M. R. (2013). The Examining Mathematical Word Problems Solving Ability under Efficient Representation Aspect. International Scientific Publications and Cosulting Services (ISPACS), 1-11.

Shodiq, L. J., \& Tirta, I. M. (2012). Analisis Soal Matematika TIMSS 2011 dengan Indeks Kesukaran Tinggi Bagi Siswa SMP. ASEAN Economic Community (AEC).

Sirate, F. S. (2012). Implementasi Etnomatematika dalam Pembelajaran Matematika pada Jenjang Pendidikan Sekolah Dasar. Lentera Pendidikan, 4(2), 41-54.

Sumiyati, W., Netriwati, \& Rakhmawati, R. (2018). Penggunaan Media Pembelajaran Geometri Berbasis Etnomatematika . Desimal: Jurnal Matematika, 1 (1), 15-21.

TIMSS. (2019). TIMSS 2019 Assessment Frameworks. TIMSS \& PIRLS International Study Center.

Vygotsky, L. (1978). Interaction Between Learning and Development. (M. Gauvain, \& M. Cole, Eds.) Reprinted with permission of Harvard University Press, 23(3), 34-41.

Widarti, A. (2013). Kemampuan Koneksi Matematis dalam Menyelesaikan Masalah Kontekstual Ditinjau dari Kemampuan Matematis Siswa. Skripsi. Jombang: STKIP PGRI Jombang.

Wulan, E. D. (2012). Penerapan Pendekatan Model Eliciting Activities (MEAS) Untuk Meningkatkan Kemampuan Pemecahan Masalah Matematis Siswa SMP. Skripsi. Bandung: FPMIPA UPI .

Yuliyanto, Y., \& Jailani, J. (2014). Pengembangan Perangkat Pembelajaran Geometri SMP Menggunakan Metode Penemuan Terbimbing pada Kelas VIII Semester II. Jurnal Riset Pendidikan Matematia, 1(1), 127 138. 